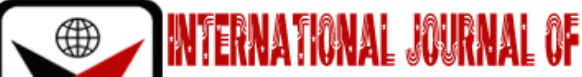

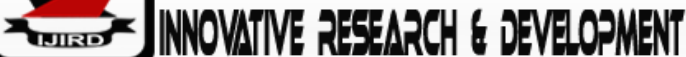

ISSN 2278 - 0211 (Online)

\section{The Prevalence of Home Injuries Mong Children Aged between 0-12 Years in Kaptembwa, Nakuru County, Kenya}

\begin{abstract}
Dr. Justus 0.0sero
Lecturer, Department of Community Health, Kenyatta University, Kenya

Wesley Too

Lecturer, Department of Clinical Medicine and Health Sciences, Kabarak University, Kenya

Phylis J. Kibet

Postgraduate Student, Department of Community Health, Kenyatta University, Kenya

Abstract:

Home Injuries are among the dominating cause of mortality and disability among children with more than 5 million deaths reported worldwide each year. Home injuries among children topped the list of top ten causes of mortality in the area in 2020. Some of the common injuries among children aged 0-12 years include: burns, falls, bites, cuts, drowning, and poisoning. The study aimed at determining the prevalence of home injuries among children aged between 0-12 years. Cross-sectional design was used among the caregivers (n=305). Interviewer schedule was used in collection of data. Data was analyzed using SPSS version 20. The overall prevalence of home injuries among the children in the previous six months was 14\%. Overly, the prevalence of boys was 3.74 higher than that of the girls. In the study, the prevalence of injury was significantly higher among male children $(p=0.001)$. The trend is highly attributed to some factors innate to boys. One of the factors is the explorative nature of boy. Boys are known to engage in dangerous and risky new games with a mind of curiosity. The general high prevalence among the children could largely be attributed to lack of supervision of the children. There is need for caregivers to keep home environment safe and limit risk factors for injuries. Additionally, children need to be supervised while playing or doing home chores.
\end{abstract}

Keywords: Home injuries, prevalence

\section{Introduction}

An injury is defined as any physical damage to the body resulting from exposure to thermal, mechanical, electrical or chemical energy in amounts that exceed human physiological threshold hence causing disturbance to normal body (Baker et al, 2013). Home injuries are a leading cause of death with more than 5 million deaths reported each year worldwide and over 950,000 children under the age of 18 die due to injury and violence (WHO, 2014).90\% of these deaths result from unintentional injuries. In Kenya, injuries among children contribute a significant burden of disease measured as years of life lost (YLL) due to premature death and is ranked second cause of death among children. Injuries are reported to be the eighth cause of mortality in Kenya (KDHS, 2018).

The age and gender of the child are important demographic factors in relation to injuries. Children between the age of 0-12 years are in a stage of development usually characterized by activeness in physical activities as they play in the playgrounds, school or at home. Such children indulge in risky activities which predispose them to such injuries as burns, fractures, dislocations, cuts, and falls. Some of the predisposing factors include the types of games they play, the responsibilities they are assigned and the physical environment they live in (Grundy and Annear, 2014).

Globally, drowning, burns, falls and poisoning account as the highest cause of mortality among children (Bener, 2015). The number of children injured or disabled each year at home is not precisely known, but has been estimated at around 10 million (Bener, 2015). In the USA, injuries are the leading cause of death for children 1-17 years old (Nixon et al., 2014).

Currently, there is very limited data in terms of epidemiology of home injuries among children, especially on prevalence. This gap has limited Public health interventions and measures needed to be taken to prevent home injuries among children. Therefore, there is need to unveil the data on prevalence of home injuries so as to improve caregiving behaviors of caregivers and also improve the quality of life of the children.

\section{Materials and Methods}

A cross-sectional study design was used to collect data on home injuries among children. The respondents comprised the caregivers of the children in Kaptembwa, Nakuru County, Kenya. Caregivers above eighteen years of age were eligible as participants and got sampled from their households. Nakuru County was randomly selected among all the forty-seven Counties in Kenya. Kaptembwa was then purposely selected due its nature of being an informal settlement 
area that increased the chances of children getting home injuries. Kaptembwa has a total of 1500 households (KNBS, 2019). Kaptembwa ward has three sub-locations namely: Mwariki, Githima and Kaptembwa and all were included in sampling of the households. The households formed the sampling unit. Systematic random sampling was used to select the household to participate for the study. The skip interval was 5, every fifth household was sampled. In cases where the household head declined to participate the next household was chosen. The sample size was calculated using Fischer's et al formula and the sample size was 305.f Adults aged above eighteen years ad were of sound mind were recruited upon consenting. Additionally, the respondents had to have been residents in the area for more than six months were recruited for this study. An interviewer schedule was used to gather the required data on both the demographic characteristics and the prevalence of home injuries among children between 0-12 years of age. The study was reviewed by the Kenyatta University Ethical and Review Committee. Permission to carry out the research was sought from the National Commission for Science and Technology (NACOSTI). Moreover, all study participants were asked to participate on voluntary basis signed a written informed consent and was free to decline or withdraw from the study at any time during the interview. The risks and benefits of the study were also communicated to the study participants prior to their participation in the study.

Quantitative pre coded data was entered into statistical program for social science (SPSS) software, version 20 for data analysis. The data operations were both analytical and descriptive. Proportions such as mean, median, frequency and range were used. Chi square was used for associations of prevalence to study variables.

\section{Results}

Majority of the caregivers were women (91\%) while only (9\%) were men. On marital status, majority (91\%) of the caregivers was married, (20.3\%) were single, while (8.2\%) widowed and (4.3\%) divorced. Majority of the caregivers (52\%) had attained primary level education, (24\%) had attained secondary school education, (20\%) had not gone to school at all while minority (4\%) of the household members had attained tertiary education. Caregivers who were selfemployed were the majority (43\%), followed by those in casual labour (22\%), housewives (19\%), permanent jobs (11\%) and farmers (5\%). Pertaining to income levels, majority (53\%) of the households had income of between KShs. 5,000 10,000 per month followed (23\%) who earned income ranging between 10,001-20,000, (15\%) of the households had income less than KShs. 5,000 per month, while those earning between 20,001-50,000 were (6\%) and minority (3\%) earning over 50,000 shillings a month.

The overall prevalence of home injuries among the children in the previous six months was $14 \%$. Overly, the prevalence of boys was 3.74 higher than that of the girls. Cuts exuded the highest prevalence (3.9\%) followed by burns $(2.5 \%)$, pricks $(1.64 \%)$, chocking (1.58\%), falls (1.5\%), bites $(1.08 \%)$, poisoning $(0.75 \%)$ and lastly, electrocution $(0.17 \%)$. The boys had a higher prevalence than the girls $(5.94 \%)$ while girls had $(2.25 \%)$. The prevalence of burns among the boys was higher than that of the girls (3.63\%) while that of girls was (1.6\%). The prevalence of pricks was slightly higher among the boys (1.94\%) and that of girls was (1.4\%). The prevalence of chocking among the boys was higher than that of the girls $(1.88 \%)$ and that of girls (1.35\%). The prevalence of falls among the boys was $(2.13 \%)$ while that of the girls was $(1 \%)$. The prevalence of bites among the boys was $(1.13 \%)$ while that of girls was $(0.6 \%)$. The prevalence of poisoning was higher among the girls (1\%) while that of boys was $(0.44 \%)$. The prevalence of electrocution was higher among the boys than the girls $(0.25 \%)$ while that of girls was $(0.1 \%)$.

\section{Discussion}

The study found that the prevalence of home injuries among the children in Kaptembwa is higher than the national prevalence by $4 \%$. Therefore, there is need to worry as the outcomes of this worrying public health concern are immensely negative. Generally, the prevalence rate of boys was higher than that of the girls; the margin was 3.74. The same results were found in a study done by (Mahalakshmy et al., 2011). In the study, the prevalence of injury was significantly higher among male children $(p=0.001)$. The trend is highly attributed to some factors innate to boys. One of the factors is the explorative nature of boy. Boys are known to engage in dangerous and risky new games with a mind of curiosity. The other factor is the little attention and supervision given to boys when playing. Boys are usually given more play time and also not restricted to the kind of games compared to the girls. A study by (Parmeswaran et al. 2017) echoes the same sentiments that unintentional injuries among children are a combination of some factors. The study cited that innate curiosity, the need to play and experimental mindset contribute immensely to injuries among children. The study found that cuts were the predominant home injury followed by burns. The study contradicted with that by (Eman et al., 2015) that found falls as the leading home injury followed by burns among children. The risk factors attributed to the injuries included lack of supervision, unsafe compounds, congested rooms and engagement of children in risky house chores. The risk factors were similar to that of a study by (Eman et al., 2015).

The most prevalent injury were cuts. The reason for high sustenance of cuts was majorly due to the responsibilities given to children. Most children would either be told to cut vegetable, fruits, spices, firewood or use jembes to dig in the farms. Especially after school hours.This tallies with a study done in Kiambu District, Kenya, by Nordberg and Kimani (2014) which found out the prevalence of injuries to be cuts or piercing. The kind of trend in the study can be explained by the fact that boys tend to be more playful than girls. The other reason could be that boys mostly engage in more dangerous games than girls and that boys are more explorative than girls. The results showed that gender influenced occurrence of injuries. More male children sustained cuts and pricks while more female children sustained burns and falls. In general, the study revealed that males were more likely to sustain injuries than their female counterparts. The study confirms findings by Wasiak et al (2015) that stated that males were 1.18 times more likely to 
experience injuries than females. Boys are more likely to sustain injuries than females because they are more risk takers, less aware of hazards and are less supervised (Towner, 2015).

\section{Conclusion}

The overall prevalence of home injuries among the children was $14 \%$. Boys had a higher prevalence than the girls by 3.74 margin. The prevalence of boys was higher in most injuries except in poisoning whereby that of girls was higher. Therefore, the study recommends that immediate preventive measures by all the concerned be taken to reduce the prevalence of home injuries among the children. Additionally, the study recommends that more research to be conducted to evaluate the role of fathers in health-seeking behaviour on home injuries sustained by children and also their role in prevention of these injuries.

\section{Acknowledgements}

The authors are grateful to the caregivers of Kaptembwa community who willingly participated in our study, the community leaders that granted us entry into the community and the research assistants who assisted in data collection. We also extend our heartfelt appreciation to the Nakuru County Government- Ministry of Health Services (Public Health) for granting us permission and goodwill in our research in its jurisdiction. advice.

Our sincere gratitude also goes to the group of experts who reviewed our work and gave us their guidance and

\begin{tabular}{|c|c|c|c|c|c|}
\hline Gender of Caregivers & Male & Female & & & \\
\hline & $17(9 \%)$ & $288(91 \%)$ & & & \\
\hline \multirow{2}{*}{$\begin{array}{l}\text { Marital status of the } \\
\text { caregivers }\end{array}$} & Married & Single & Widowed & Separated/Divorced & \\
\hline & $205(91 \%)$ & $62(20.3 \%)$ & $25(8.2 \%)$ & $13(4.3 \%)$ & \\
\hline \multirow[t]{2}{*}{$\begin{array}{c}\text { Level of education of } \\
\text { caregivers }\end{array}$} & Primary & Secondary & $\begin{array}{l}\text { No formal } \\
\text { education }\end{array}$ & Tertiary education & \\
\hline & $159(52 \%)$ & $73(24 \%)$ & $61(20 \%)$ & $12(4 \%)$ & \\
\hline \multirow[t]{2}{*}{$\begin{array}{l}\text { Occupation of } \\
\text { caregivers }\end{array}$} & $\begin{array}{c}\text { Self- } \\
\text { employed }\end{array}$ & Casual labour & House wife & $\begin{array}{l}\text { Permanent } \\
\text { employment }\end{array}$ & Farming \\
\hline & $131(43 \%)$ & $67(22 \%)$ & $58(19 \%)$ & $34(11 \%)$ & $15(5 \%)$ \\
\hline \multirow[t]{2}{*}{$\begin{array}{l}\text { Household monthly } \\
\text { income }\end{array}$} & $\begin{array}{c}\text { Below kshs } \\
5,000\end{array}$ & $\begin{array}{c}\text { Kshs } 5,000- \\
10,000\end{array}$ & $\begin{array}{c}\text { Kshs } 10,000- \\
20,000\end{array}$ & Kshs $20,000-50,000$ & $\begin{array}{l}\text { Above } \\
50,000\end{array}$ \\
\hline & $46(15 \%)$ & $162(53 \%)$ & $70(23 \%)$ & $18(6 \%)$ & $9(3 \%)$ \\
\hline
\end{tabular}

Table 1: Demographic Characteristics

\section{The Prevalence of Home Injuries}

$$
\begin{aligned}
& \text { Variablen } \\
& \text { Proportion (\%) Prevalence } \\
& \text { Gotal } 490 \\
& \text { Boys } 251 \\
& \text { Girls } 239 \\
& \text { Type of injury } 100 \\
& \text { Burns } 90 \quad 100 \\
& \text { Pricks } 59 \\
& \text { Chocking } 57 \\
& \text { Bites } 39 \\
& \text { Pois oninge } 7 \text {. } \\
& 6100 \\
& \text { Distribution of injury per gender } \\
& \text { Girls } 45 \\
& \text { Girls } \\
& \text { Boys } 58 \\
& \text { Girls } 32 \\
& \text { Pricks } \\
& \text { Boys } 31 \\
& \text { Girls } \\
& \text { Chockine } \\
& \text { Boys } 27 \\
& \text { Falls } \\
& \text { Boys } 34 \\
& \text { Girls } \\
& \text { Bites } 18 \\
& \text { Goys } 18 \\
& \text { Poisoning } \\
& \text { Boys } 7 \\
& \text { Electrocution } \\
& \text { Boys } 4 \\
& 51.22 \quad 15.69 \% \\
& 8.78 \quad 11.95 \% \\
& 3.9 \% \\
& \begin{array}{l}
2.5 \% \\
100 \quad 1.64 \%
\end{array} \\
& 100 \quad 1.58 \% \\
& 1.5 \% \\
& 100 \quad 0.75 \% \\
& 32.14 \quad 2.25 \% \\
& \begin{array}{ll}
64.44 & 3.63 \% \\
35.56 & 1.6 \%
\end{array} \\
& \begin{array}{ll}
52.5 & 1.94 \% \\
47.5 & 1.4 \%
\end{array} \\
& \begin{array}{ll}
52.63 & 1.88 \% \\
47.37 & 1.35 \%
\end{array} \\
& 47.37 \quad 1.35 \% \\
& \begin{array}{ll}
63 & 2.13 \%
\end{array} \\
& 60 \quad 1.13 \% \\
& 40 \quad 0.6 \% \\
& \begin{array}{ll}
26 & 0.44 \% \\
74 & 1 \%
\end{array} \\
& 66.67 \quad 0.25 \% \\
& 33.33 \quad 0.1 \%
\end{aligned}
$$

Table 2: The Prevalence of Home Injuries among Children Aged between 0-12 Years 


\section{References}

i. Bener A. The neglected epidemic; injuries and accidents in developing country. Stat Qatar, Int J/njContrsaFPromot, 2005, vol.12 (pg.45-47).

ii. Eman, J. C., Miller, A., Raina, P., \&McGrail, K. M. (2003). Childhood behavior disorders and injuries among children and youth: a population-based study. Pediatrics, 111(2), 262-269.

iii. Grundy, J., \& Annear, P. (2010). Health-seeking behaviour studies: a literature review of study design and methods with a focus on Cambodia. Health policy and health finance knowledge hub working paper series no, 7.

iv. Kenya Demographic and Health Survey 2014. Demographic and Health Survey.

v. Kenya National Bureau of Statistics. 2019 Kenya Population and Housing Census Volume I: Population by County and Sub-County

vi. Mahalakshmy, T., Dongre, A. R., \&Kalaiselvan, G. (2011). Epidemiology of childhood injuries in rural Puducherry, South India. The Indian Journal of Pediatrics, 78(7), 821-825.

vii. Nixon, J.,Norton, C., \&Sibert, J. R. (2004). Playground injuries to children. Archives of disease in childhood, 89(2), 103-108.

viii. Nordberg, E., Kimani, V., \&Diwan, V. (2014). Household survey of injuries in a Kenyan district. East African medical journal, 77(5).

ix. Parmeswaran, G. G., Kalaivani, M., Gupta, S. K., Goswami, A. K., \&Nongkynrih, B. (2017). Unintentional childhood injuries in urban Delhi: A community-based study. Indian journal of community medicine: official publication of Indian Association of Preventive \& Social Medicine, 42(1), 8.

x. Puducherry, South India. The Indian Journal of Pediatrics, 78(7), 821-825.

xi. Towner, E., Dowswell, T., Mackereth, C., \& Jarvis, S. (2001). What works in preventing unintentional injuries in children and young adolescents: an updated systematic review.Database of Abstracts of Reviews of Effects (DARE): Quality-assessed Reviews [Internet].

xii. Wasiak, J., Spinks, A., Ashby, K., Clapperton, A., Cleland, H., \&Gabbe, B. (2009). The epidemiology of burn injuries in an Australian setting, 2000-2006. Burns, 35(8), 1124-1132.

xiii. World Health Organization. Injuries, Violence Prevention Department, World Health Organization, World Health Organization. Department of Injuries,\& Violence Prevention. (20014) The injury chart book: a graphical overview of the global burden of injuries. World Health Organization. 